\title{
June 22 Highlight and Commentary
}

\section{Dysembryoplastic neuroepithelial tumor (DNT) in childhood}

Nolan et al. examined the long-term outcome and prognostic features of DNT-associated epilepsy in 26 children managed surgically. Although $85 \%$ of children were seizure-free at 1 year, at longer follow-up this fell to $62 \%$. Residual tumor on postoperative MRI was the most important factor in predicting long-term seizure outcome.

see page 2270

Commentary by Scott Pomeroy, MD

Dysembryoplastic neuroepithelial tumors (DNT) are glial-neuronal neoplasms that occur in children or young adults, typically in association with long-standing intractable partial seizures. ${ }^{1}$ They localize in cortex and inconsistently enhance on MRI, and are characterized by columns of axon/oligodendroglial bundles that surround neurons floating in a pale, eosinophilic matrix. Frequently they are associated with cortical dysplasias. DNTs are thought to be dysembryoplastic in origin and without potential for recurrence once surgically removed. ${ }^{2}$

Nolan et al. extend our understanding of their natural history by following 26 children with DNT for up to 11 years after initial diagnosis and resection. They report an initial favorable prognosis for seizure control, with $85 \%$ of children free of seizures 1 year after diagnosis. Longer follow-up, however, demonstrates seizure recurrence in many other children. At the end of the study, only $65 \%$ remained free of seizures with mean follow-up of 4.3 years. Moreover, three of the children had tumor recurrence. This adds to a growing literature indicating that

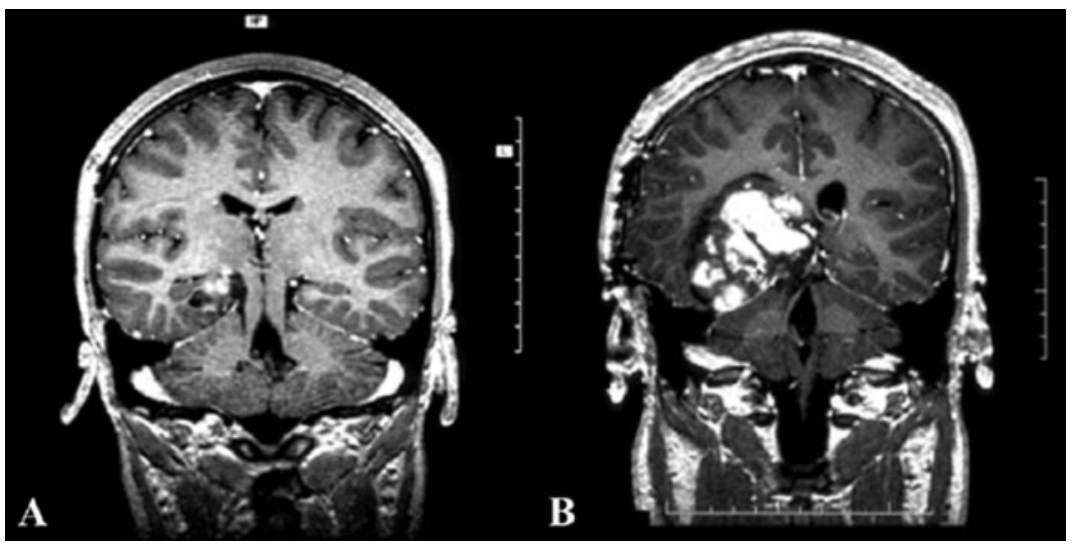

Recurrence of DNT, gadolinium enhanced coronal T1-weighted images. A. Postoperatively, there is residual enhancing DNT visible in medial right temporal lobe. B. Same patient, 3 years later. DNT recurrence with increase in size of mass.

DNTs can recur after resection, and may even undergo malignant transformation. ${ }^{3}$

Collectively, these results support a need for close follow-up of children and young adults who have been diagnosed and treated for DNT, monitoring for recurrence of seizures and for potential of regrowth of the tumor.

\section{References}

1. Daumas-Duport C, Scheithauer BW, Chodkiewicz JP, et al. Dysembryo- plastic neuroepithelial tumor: a surgically curable tumor of young patients with intractable partial seizures. Report of thirty-nine cases. Neurosurgery 1988;23:545-556.

2. Daumas-Duport C, Pietsch T, Lantos PL. Dysembryoplastic neuroepithelial tumors. In: Kleihues P, Cavinee WK, eds. WHO classification: tumours of the nervous system. Lyon: International Agency for Research on Cancer, 2000: 103-106.

3. Hammond RR, Duggal N, Woulfe JMJ, Girvin JP. Malignant transformation of a dysembryoplastic neuroepithelial tumor. J Neurosurg 2000;92:722-725. 


\section{Neurology}

June 22 Highlight and Commentary

Neurology 2004;62;2147

DOI 10.1212/01.WNL.0000132259.44101.F2

\section{This information is current as of June 21, 2004}

\section{Updated Information \&} Services

References

Permissions \& Licensing

Reprints including high resolution figures, can be found at: http://n.neurology.org/content/62/12/2147.full

This article cites 2 articles, 0 of which you can access for free at: http://n.neurology.org/content/62/12/2147.full\#ref-list-1

Information about reproducing this article in parts (figures,tables) or in its entirety can be found online at:

http://www.neurology.org/about/about_the_journal\#permissions

Information about ordering reprints can be found online:

http://n.neurology.org/subscribers/advertise

Neurology ${ }^{\circledR}$ is the official journal of the American Academy of Neurology. Published continuously since 1951, it is now a weekly with 48 issues per year. Copyright . All rights reserved. Print ISSN: 0028-3878. Online ISSN: 1526-632X.

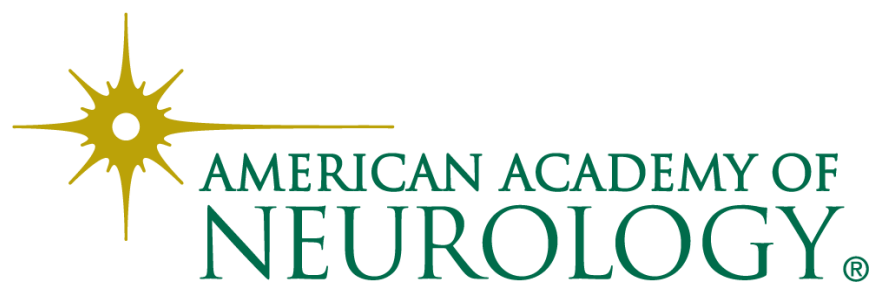

